\title{
COMPARISON OF ENDOTHELIAL CELL LOSS AFTER PHACOEMULSIFICATION AND MANUAL SMALL INCISION CATARACT SURGERY
}

\author{
Papineni Satyavani ${ }^{1}$, Srinivas Prasad Killani², Atti Sri Hari ${ }^{3}$, Superna Mahendra ${ }^{4}$, Suneesha Gajula 5 \\ ${ }_{1}^{1}$ Assistant Professor, Department of Ophthalmology, Osmania Medical College, Hyderabad. \\ ${ }^{2}$ Assistant Professor, Department of Ophthalmology, Osmania Medical College, Hyderabad. \\ ${ }^{3}$ Associate Professor, Department of Ophthalmology, Osmania Medical College, Hyderabad. \\ ${ }_{4}^{4}$ Assistant Professor, Department of Ophthalmology, Osmania Medical College, Hyderabad. \\ 5Postgraduate, Department of Ophthalmology, Osmania Medical College, Hyderabad.
}

\begin{tabular}{l}
\hline ABSTRACT \\
\hline BACKGROUND \\
Endothelial cell loss during cataract surgery leads to corneal decompensation and visual loss. \\
OBJECTIVES \\
To compare endothelial cell loss after cataract surgery, phacoemulsification versus manual Small-Incision Cataract Surgery \\
(SICS), by specular microscope as MSICS is still the most common type of cataract surgery done in our country.
\end{tabular}

\section{STUDY DESIGN}

Prospective interventional randomised comparative study in SDEH, Osmania Medical College, Hyderabad between Jan. 2013 and Aug. 2014.

\section{MATERIAL AND METHODS}

100 patients of age $>40$ years with senile cataract of NS Gr II and NS Gr III and divided into 2 groups of 50 each. A complete ophthalmologic examination and endothelial cell count by specular microscopy were performed preoperatively and 1 and 6 weeks postoperatively in all patients undergoing cataract surgery. Patients were randomly allocated to undergo SICS or phacoemulsification by same surgeon.

\section{RESULTS}

The study evaluated 100 patients, 50 in each group. The mean preoperative endothelial cell density was 2575 cells $/ \mathrm{mm}^{2}$ in the phacoemulsification group and 2535 cells $/ \mathrm{mm}^{2}$ in the SICS group (P - 0.8397). The difference at 6 weeks was 169.90 cells $/ \mathrm{mm}^{2}$ and 202.80 cells $/ \mathrm{mm}^{2}$ in phacoemulsification group and SICS group respectively $(\mathrm{P}=0.5928)$.

\section{CONCLUSION}

There was no clinically or statistically significant difference in endothelial cell loss between phaco and SICS in the hands of an experienced surgeon.

\section{KEYWORDS}

Endothelial Cell Count, Specular Microscopy, Phacoemulsification, SICS.

HOW TO CITE THIS ARTICLE: Satyavani P, Killani SP, Hari AS, et al. Comparison of endothelial cell loss after phacoemulsification and manual small incision cataract surgery. J. Evolution Med. Dent. Sci. 2016;5(73):5410-5415, DOI: 10.14260/jemds/2016/1227

\section{INTRODUCTION}

The Mean Endothelial Density (ECD) in the normal adult cornea ranges from 2000 to 2500 cells $/ \mathrm{mm}^{2}$, and the count continues to decrease with age. Morphological stability and functional integrity of the corneal endothelium are necessary to maintain long-term corneal transparency after cataract surgery. Endothelial cell loss and corneal decompensation after cataract surgery is well-documented. The first reported evaluation of the corneal endothelium was by Vogt in $1918 .{ }^{1}$

Financial or Other, Competing Interest: None.

Submission 14-06-2016, Peer Review 25-08-2016,

Acceptance 02-09-2016, Published 12-09-2016.

Corresponding Author:

Dr. Papineni Satyavani,

Assistant Professor,

Sarojini Devi Eye Hospital,

Humayun Nagar, Mehdipatnam,

Hyderabad-500028, Telangana.

E-mail: drpsatyavani@gmail.com

DOI: $10.14260 /$ jemds/2016/1227
He visualised the endothelial mosaic with specular reflection while performing slit-lamp biomicroscopy. For 50 years, this technique was standard-of-care when evaluating the corneal endothelium. In 1968, David Maurice ${ }^{2}$ developed a microscope to visualise the corneal endothelium and introduced the term specular microscope.

All surgical procedures that involve entry into the anterior chamber damage, a proportion of endothelial cells intraoperative corneal manipulation. After endothelial cell loss, the adjacent cells enlarge and slide over to maintain endothelial cell continuity, which is observed as a change in the endothelial cell density and morphology. Moderate damage to the endothelium during surgery can also lead to a transient increase in corneal thickness. Endothelial cell density and function can be assessed clinically using specular microscopy and pachymetry.

In developing countries such as India where there is a cataract backlog, MSICS with Intraocular Lens (IOL) implantation promises to be a viable cost-effective alternative to phacoemulsification. In India approximately 5 million 
cataract surgeries are performed per year; therefore, it is important to determine the safest surgical technique for the endothelium. There is a paucity of data from India on the effect of Small-Incision Cataract Surgery (SICS) and phacoemulsification on the corneal endothelium, so our study was performed to assess the postoperative endothelial cell loss and change in endothelial morphology over a short period of time between the two commonly performed cataract techniques.

\section{AIMS AND OBJECTIVES OF THE STUDY}

This study aims at comparing the endothelial cell loss after Manual Small Incision Cataract Surgery (MSICS) and Phacoemulsification by specular microscopy.

\section{METHODOLOGY}

\section{Inclusion Criteria}

100 patients of age $>40$ years with senile cataract of NS Gr II and NS Gr III.

\section{Exclusion Criteria}

- Traumatic cataract.

- Complicated cataract.

- Corneal diseases (Fuchs' dystrophy).

- Other causes of decreased vision (Diabetes, Glaucoma).

Intraoperative posterior capsular rupture and vitreous loss. The study population consisted of 100 eyes of 100 patients who were age matched and sex matched were divided into two groups; 50 eyes were included in each group. All the patients underwent complete ophthalmic examination with Slit Lamp Examination, Gonioscopy and endothelial cell density by Specular Microscopy EM-3000, Tomey. Group I patients underwent Phacoemulsification and Group II underwent Manual Small Incision Cataract Surgery (MSICS) by same surgeon during period of January 2013 to August 2014 at Sarojini Devi Eye Hospital, Hyderabad. The patients were evaluated by specular microscopy for endothelial cell density postoperatively on 1st postoperative day, 1 week postoperative, 6 week postoperative and 6 months postoperative.

\section{Image Analysis}

In the study endothelial cell density ${ }^{3}$ is measured by EM 3000, Tomey; 15 shots are taken in series and best image among 15 images is automatically selected and displayed on screen. The software for automatic analysis is pre-installed and image is analysed automatically.

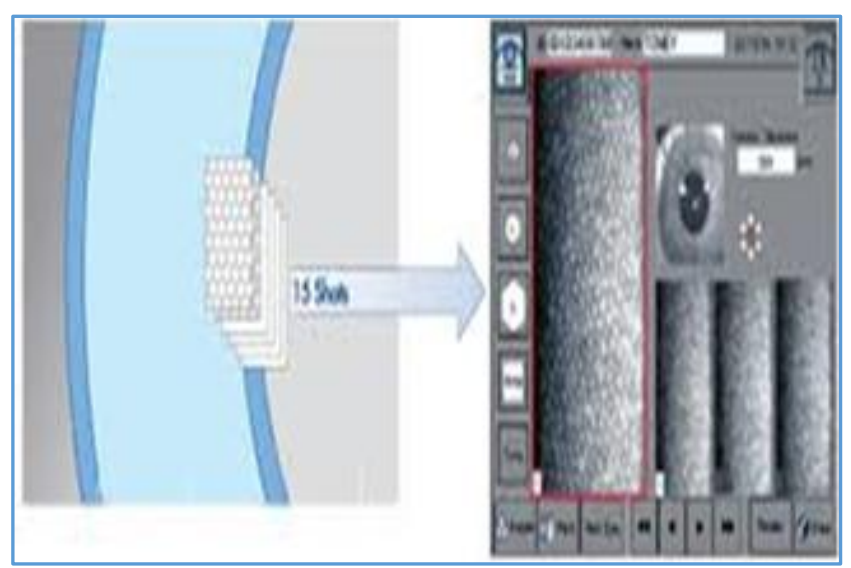

Fig. VII: Image Analysis

\section{Statistical Analysis}

All data obtained were recorded and presented as mean with standard deviation. Student paired T - test was used on all continuous data to calculate statistical significant difference between preoperative and postoperative values within same group. Student unpaired T-test was used to calculate the statistical significant difference between different group values. The statistical significance is taken when $p$-value $<0.05$.

\section{RESULTS}

Present study included 50 patients who underwent phacoemulsification (Group 1) and 50 patients who underwent MSICS (Group 2) by the same surgeon. The mean age of Group I was 58 years (95\% Confidence interval; 55 - 61 years) 59 years [95\% confidence interval: $54-64$ years] and for Group II. There was no statistically significant difference in age between groups (p-value - 0.3320).

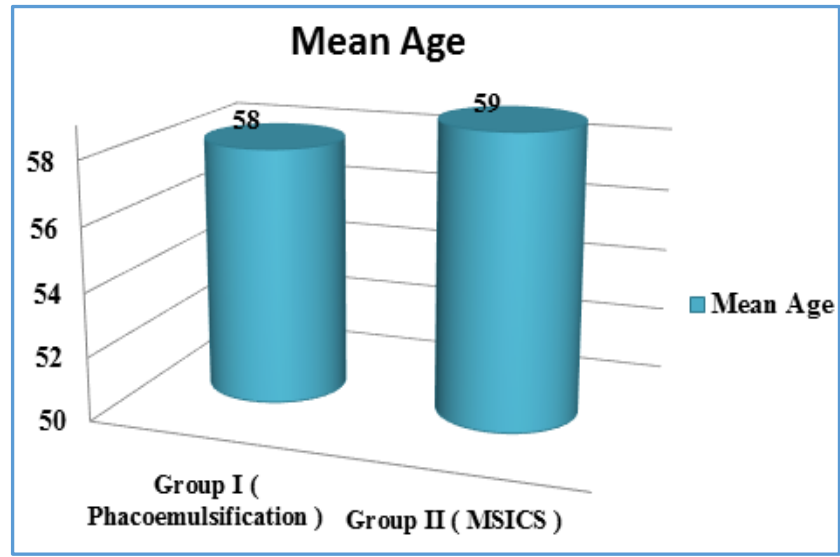

Graph I: Mean Age among Group I and Group II

\begin{tabular}{|c|c|c|c|}
\hline & $\begin{array}{c}\text { Group I } \\
\text { Phacoemulsification }\end{array}$ & $\begin{array}{c}\text { Group II } \\
\text { MSICS }\end{array}$ & $\begin{array}{c}\text { P - } \\
\text { Value }\end{array}$ \\
\hline $\begin{array}{c}\text { Mean Age } \\
\text { (yrs.) }\end{array}$ & 58 & 59 & 0.3320 \\
\hline \multicolumn{3}{|c|}{ Table I: Mean Age Distribution among } \\
Group I and Group II \\
\hline
\end{tabular}

In the study, 25 males and 25 females in each group were included. There was no statistically significant differance in sex distribution between Group I and Group II ( $p$ - value 1.0).

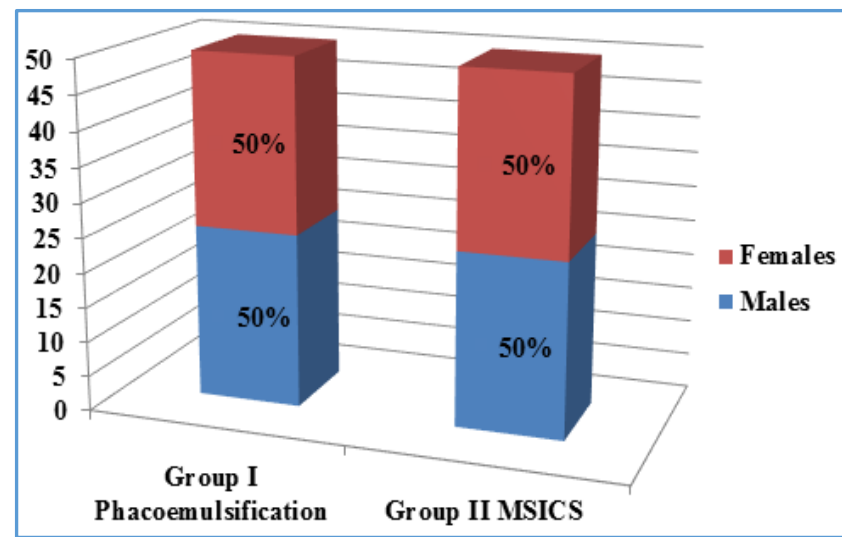

Graph II: Sex Distribution among Group I and Group II 


\begin{tabular}{|c|c|c|c|}
\hline & Group I & Group II & P - Value \\
\hline Males & 25 & 25 & 1.0 \\
\hline Females & 25 & 25 & 1.0 \\
\hline \multicolumn{4}{|l|}{ Table II: Sex Distribution among Group I and Group II } \\
\hline
\end{tabular}

In the study, 23 patients had NS Gr II (46\%) and 27 patients had NS Gr III (54\%) in each group were included. There was no statistically significant difference in lenticular opacity distribution between Group I and Group II (p value - 1.00).

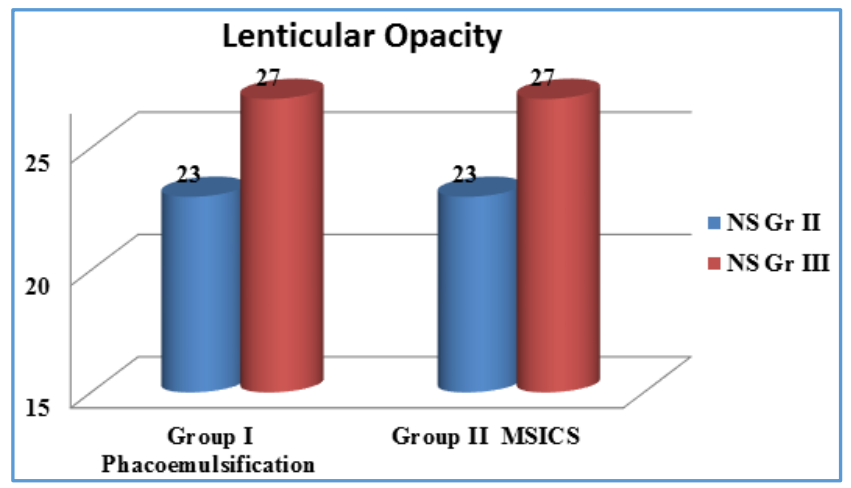

Graph III: Distribution of Lenticular Opacity

\begin{tabular}{|c|c|c|c|}
\hline & NS Gr II & NS Gr III & P Value \\
\hline Group I & 23 & 27 & \\
Phacoemulsification & $(46 \%)$ & $(54 \%)$ & \multirow{2}{*}{1.00} \\
\cline { 1 - 3 } Group II & 23 & 27 & \\
MSICS & $(46 \%)$ & $(54 \%)$ & \\
\hline \multicolumn{3}{|c|}{ Table III: Distribution of Lenticular Opacity } \\
\hline
\end{tabular}

The mean preoperative endothelial cell density was 2575 cell/mm² (95\% CI: 2285 - 2866) in Group I and 2535 cell $/ \mathrm{mm}^{2}$ (95\% CI: 2274 - 2895) in Group II. There was no statistical significance in preoperative ECD between Group I and Group II ( $p$ value - 0.8397 ).

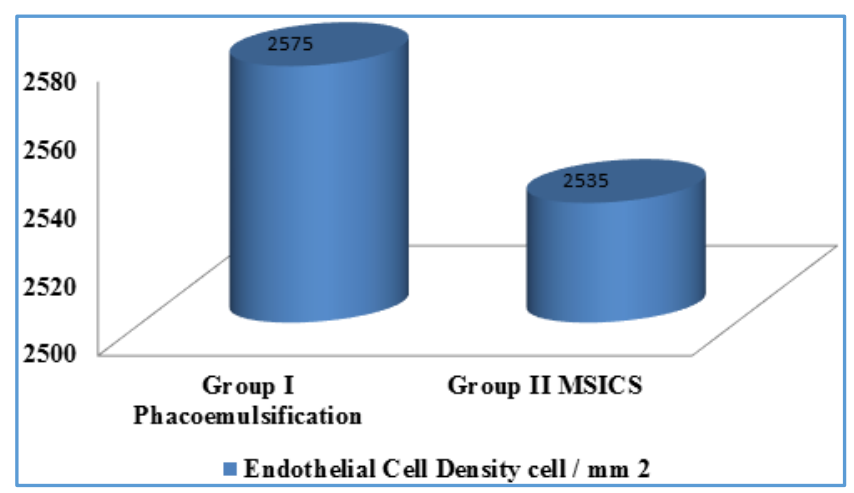

Graph IV: Preoperative Endothelial Cell Density

\begin{tabular}{|c|c|c|c|}
\hline & $\begin{array}{c}\text { Group } \\
\text { I }\end{array}$ & $\begin{array}{c}\text { Group } \\
\text { II }\end{array}$ & $\begin{array}{c}\text { P - } \\
\text { Value }\end{array}$ \\
\hline $\begin{array}{c}\text { Mean Endothelial Cell } \\
\text { Density (Cells/mm }{ }^{2} \text { ) }\end{array}$ & 2575 & 2535 & 0.8397 \\
\hline Table IV: Mean Preoperative Endothelial Cell Density \\
\hline
\end{tabular}

The 100 patients, i.e. 50 patients in Group I underwent Phacoemulsification and 50 patients in Group II underwent MSICS by same surgeon. Endothelial Cell Density was calculated postoperatively on day 1, 1 week and 6 weeks and 6 months by EM 3000, Specular Microscope. Comparison of mean ECL was done between two groups. The mean endothelial cell loss on first postoperative day in Group I was 266 Cells $/ \mathrm{mm}^{2}$ (95\% confidence interval - 243 - 289) and in Group II was 273 Cells/ $\mathrm{mm}^{2}$ (95\% confidence interval - 240 306). There was no statistically significant difference of mean ECL between Group I and Group II on first postoperative day (p value - 0.6578).

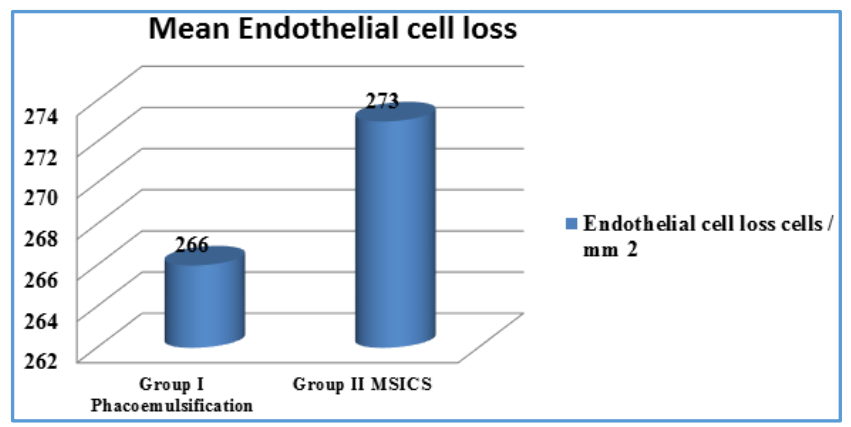

Graph V: Mean Endothelial Cell Loss on 1 st Postoperative Day

\begin{tabular}{|c|c|c|c|}
\hline & $\begin{array}{c}\text { Group } \\
\text { I }\end{array}$ & $\begin{array}{c}\text { Group } \\
\text { II }\end{array}$ & $\begin{array}{c}\text { P - } \\
\text { Value }\end{array}$ \\
\hline $\begin{array}{c}\text { Mean Preoperative ECD } \\
\left(\text { Cells } / \mathrm{mm}^{2}\right)\end{array}$ & 266 & 273 & 0.6578 \\
\hline \multicolumn{3}{|c|}{ Table V: Mean Endothelial Cell Loss on } \\
1st Postoperative Day
\end{tabular}

The mean endothelial cell loss at 1 week in Group I was 200 Cells $/ \mathrm{mm}^{2}$ (95\% confidence interval - 190 to 210) and in Group II was 250 Cells $/ \mathrm{mm}^{2}$ (95\% confidence interval - 230 to 270). There was no statistically significant difference of mean ECL between Groups at 1 week postoperative (P value 0.4299 )

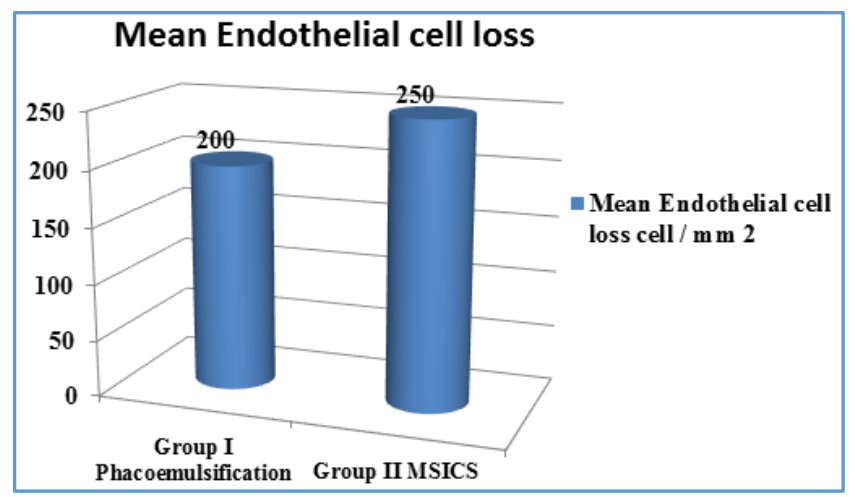

Graph VI: Mean Endothelial Cell Loss at 1 Week Postoperative

\begin{tabular}{|c|c|c|c|}
\hline & $\begin{array}{c}\text { Group } \\
\text { I }\end{array}$ & $\begin{array}{c}\text { Group } \\
\text { II }\end{array}$ & $\begin{array}{c}\text { P - } \\
\text { Value }\end{array}$ \\
\hline $\begin{array}{c}\text { Mean Endothelial Cell } \\
\text { Loss } \\
\left(\text { Cells/mm } / \mathrm{mm}^{2}\right)\end{array}$ & 200 & 250 & 0.4299 \\
\hline \multicolumn{3}{|c|}{$\begin{array}{c}\text { Table VI: Mean Endothelial Cell Loss at 1 Week } \\
\text { Postoperative }\end{array}$} \\
\hline
\end{tabular}

The mean endothelial cell loss at 6 weeks postoperative in Group I was 185 Cells $/ \mathrm{mm}^{2}$ (95\% confidence interval - 159 211) and in Group II was 230 Cells $/ \mathrm{mm}^{2}$ (95\% confidence interval - 210 - 250). There was no statistically significant difference of mean ECL between Group I and Group II at 6 weeks postoperative (P value 0.3216 ). 


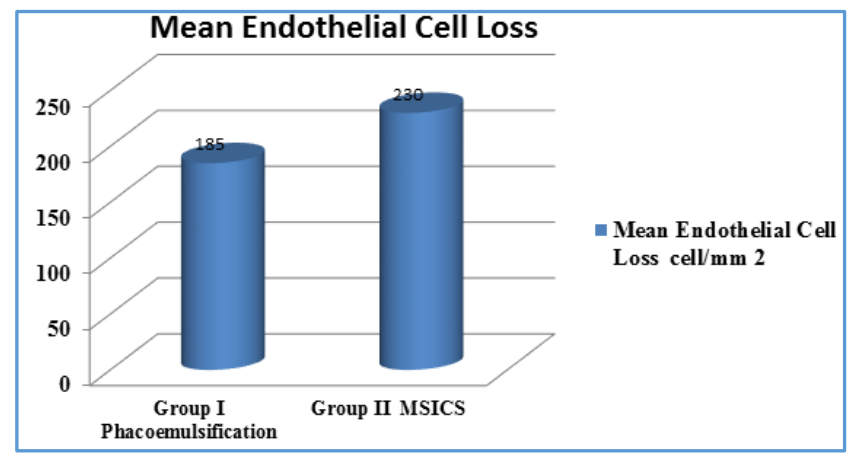

Graph VII: Mean Endothelial Cell Loss at 6 Weeks Postoperative

\begin{tabular}{|c|c|c|c|}
\hline & $\begin{array}{c}\text { Group } \\
\text { I }\end{array}$ & $\begin{array}{c}\text { Group } \\
\text { II }\end{array}$ & $\begin{array}{c}\text { P - } \\
\text { Value }\end{array}$ \\
\hline $\begin{array}{c}\text { Mean Endothelial Cell } \\
\text { Loss } \\
\left(\text { Cells/mm } / \mathrm{mm}^{2}\right)\end{array}$ & 185 & 230 & 0.3216 \\
\hline \multicolumn{3}{|c|}{ Table VII: Mean Endothelial Cell Loss at 6 Weeks } \\
Postoperative
\end{tabular}

The mean endothelial cell loss at 6 months postoperative in Group I was 169 Cells/ $\mathrm{mm}^{2}$ (95\% confidence interval - 144 -194) and in Group II was 202 Cells $/ \mathrm{mm}^{2}$ (95\% confidence interval - 175 - 229). There was no statistically significant difference of mean ECL between Group I and Group II at 6 months postoperative (P value 0.5928).

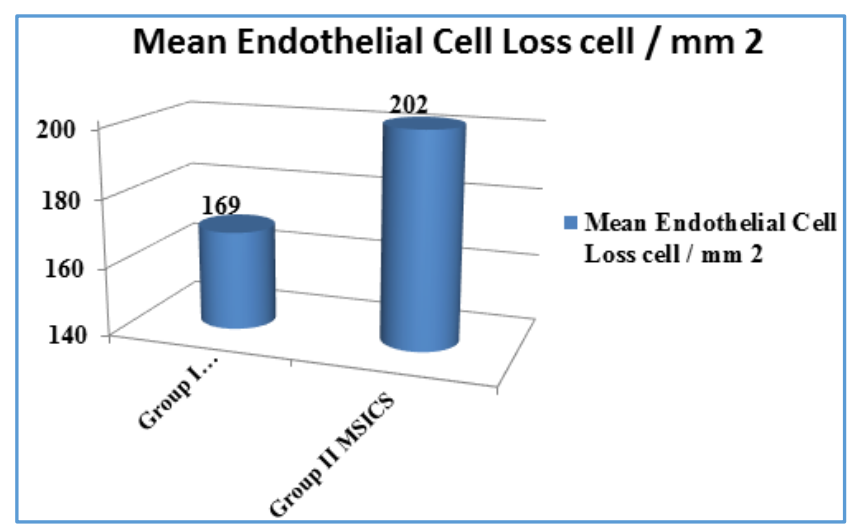

Graph VIII: Mean Endothelial Cell Loss at 6 Months Postoperative

\begin{tabular}{|c|c|c|c|}
\hline & Group I & Group II & P - Value \\
\hline $\begin{array}{c}\text { Mean Endothelial Cell } \\
\text { Loss } \\
\left(\text { Cells } / \mathrm{mm}^{2}\right)\end{array}$ & 169.90 & 202.80 & 0.5928 \\
\hline \multicolumn{3}{|c|}{ 6able VIII: Mean Postoperative Endothelial Cell Loss at } \\
\hline
\end{tabular}

\section{SUMMARY}

\begin{tabular}{|c|c|c|c|c|}
\hline & $\begin{array}{c}\text { Group } \\
\text { I }\end{array}$ & $\begin{array}{c}\text { Group } \\
\text { II }\end{array}$ & $\begin{array}{c}P \text { - } \\
\text { Value }\end{array}$ & \\
\hline Mean Age & 58 yrs. & 59 yrs. & 0.3220 & \\
\hline \multirow{2}{*}{ Sex } & Males & 25 & 25 & 1.000 \\
\hline & Females & 25 & 25 & 1.000 \\
\hline $\begin{array}{l}\text { Preopera- } \\
\text { tive ECD } \\
\left(\text { Cells } / \mathrm{m}^{2}\right)\end{array}$ & 2575 & 2535 & 0.8397 & \\
\hline $\begin{array}{c}\text { Mean ECL at } \\
1^{\text {st }} \text { POD } \\
\left(\text { Cells } / \mathrm{mm}^{2}\right)\end{array}$ & 266 & 273 & 0.6578 & \\
\hline
\end{tabular}

\begin{tabular}{|c|c|c|c|}
\hline $\begin{array}{c}\text { Mean ECL at } \\
1 \text { week } \\
\text { Post- } \\
\text { operative } \\
\text { (Cells } / \mathrm{mm} 2 \text { ) }\end{array}$ & 200 & 250 & 0.4299 \\
\hline $\begin{array}{c}\text { Mean } \\
\text { Endothelial } \\
\text { Cell Loss at } 6 \\
\text { weeks Post- } \\
\text { operative } \\
\text { (Cells/mm2) }\end{array}$ & 185 & 230 & 0.3216 \\
\hline $\begin{array}{c}\text { Mean } \\
\text { Endothelial } \\
\text { Cell Loss at } 6 \\
\text { months Post- } \\
\text { operative } \\
\text { (Cells/mm2) }\end{array}$ & 169 & 202 & 0.5928 \\
\hline Table IX: & $\mathrm{III}$ & ails of & Study \\
\hline
\end{tabular}

The Results of Present Study Compared with Previous Study

\begin{tabular}{|c|c|c|c|c|c|c|}
\hline & 官 & 竞 & $\begin{array}{l}\frac{0}{3} \\
\underbrace{\pi} \\
1\end{array}$ & 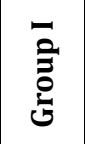 & 를 & $\begin{array}{l}\frac{0}{3} \\
\sum^{\pi} \\
1\end{array}$ \\
\hline $\begin{array}{c}\text { Preoperative } \\
\text { Endothelial Cell } \\
\text { Density } \\
\left(\text { Cells } / \mathrm{mm}^{2}\right) \\
\end{array}$ & 2575 & 2535 & 0.8397 & 2852 & 2950 & 0.6324 \\
\hline $\begin{array}{l}\text { Mean Endothelial } \\
\text { Cell Loss at } 6 \\
\text { weeks Post- } \\
\text { Operative } \\
\left(\text { Cells } / \mathrm{mm}^{2}\right)\end{array}$ & 185 & 230 & 0.3216 & 456 & 474 & 0.987 \\
\hline Table & $\begin{array}{l}\text { om } \\
\text { vith }\end{array}$ & iso & $\begin{array}{l}\text { of Pr } \\
\text { us Stu }\end{array}$ & $t$ & & \\
\hline
\end{tabular}

\section{DISCUSSION}

Manual small-incision techniques are gaining popularity as quick, relatively inexpensive techniques for large-scale cataract management in the developing world. Phacoemulsification has been shown to be safe for the corneal endothelium. ${ }^{4,5}$

However, postoperative visual acuity and complication rates are the same phacoemulsification and SICS. ${ }^{6}$

Endothelial alteration is considered an important parameter of surgical trauma and essential for estimating the safety of the surgical technique. After cataract surgery, endothelial cell density decreases at a greater rate than in healthy, unoperated corneas. There is a wide variation in endothelial cell loss between the various studies even when the mode of surgery is same (e.g. SICS). This is due to various factors including different inclusion and exclusion criteria, different grades of cataract, different methods of nucleus delivery in SICS, different types of irrigating solution and viscoelastics. The reported endothelial loss varies between $4 \%$ and $25 \%$, and the period of increased postoperative endothelial cell loss remains unknown. ${ }^{7}$ Endothelial cell loss begins soon after surgery, continues for at least 10 years postoperatively and may throughout the patient's life.

A study comparing phacoemulsification and conventional ECCE $^{8}$ reported a $10 \%$ reduction in endothelial cells in both groups. In a study comparing endothelial cell loss after conventional ECCE, MSICS and phacoemulsification, ${ }^{9}$ the ECC decreased by $4.72 \%, 4.21 \%$ and $5.41 \%$ respectively with no 
significant difference between the three groups. Another study evaluated endothelial cell damage after phacoemulsification and planned ECCE with different capsulotomy techniques. The mean cell loss was $11.8 \%$ in the phacoemulsification group, $12.8 \%$ in the ECCE group that underwent CCC and $10.1 \%$ in the ECCE group that underwent letterbox capsulotomy.

In the present study, over 6 months there was decrease in cell density of 169 cells $/ \mathrm{mm}^{2}$ for phacoemulsification and 202 cells $/ \mathrm{mm}^{2}$ for MSICS. This difference in mean endothelial cell density was not statistically significant $(P=0.5928)$. This depicts that in Group 1 and Group 2 the mean endothelial cell density at 1 week, 6 weeks and 6 months stabilised and was maintained. The SICS technique carries greater risk of endothelial loss that is mainly attributed to surgical manipulation in the anterior chamber close to corneal endothelium and endothelial trauma during the nucleus delivery from the anterior chamber. Various modifications of SICS (irrigating vectis, viscoexpression of the nucleus, anterior chamber maintainer, high density viscoelastics) have significantly reduced the endothelial cell loss. In phacoemulsification, the manoeuvring is mechanical and performed in the capsular bag, distantly from the endothelium and newer advanced phacoemulsification units with better fluidics may reduce the chances of endothelial damage.

One of the limitations of this study was that only 1 technique of phacoemulsification and one technique of SICS were compared; other techniques may give different results. In addition, stainless steel blades instead of diamond knives were used for phacoemulsification and sodium hyaluronate $1.4 \%$ (Healon GV) was not used in order to reduce the cost of the surgery. A viscoelastic with higher retention may have resulted in less endothelial cell loss. An Indian study has shown that safety to the endothelium was similar with the use of sodium hyaluronate for phacoemulsification and HPMC for MSICS. Another study from Italy has shown no significant decrease in mean endothelial cell density with the use of four different viscoelastics (HPMC, Healon, Healon GV and Viscoat). Hence, we opted for HPMC in MSICS. 10

A study from Italy ${ }^{11}$ compared endothelial cell damage between scleral tunnel incisions and clear corneal tunnel. Contrary to our study concluded that scleral tunnels led to less postoperative endothelial cell damage than clear corneal tunnels. Because MSICS was performed through the scleral tunnel incision, it may have caused less endothelial cell loss than phacoemulsification performed through a clear corneal tunnel incision.

Another major weakness of our study was the short-term follow-up (6 months). However, a prospective study from United States evaluating the long-term safety (5 years) of phakic IOL's found that the rate of endothelial cell loss decreases over time.12 This agrees with short-term studies, which report a higher rate of endothelial cell loss than longer studies. Endothelial cell loss is more likely related to corneal endothelial cell remodeling after the trauma of surgery than to ongoing age-related cell loss. A study comparing the effect of different phacoemulsification techniques on corneal endothelial cells found similar outcomes at 3 months and 1 year, postoperatively. ${ }^{13}$ Based on this outcome, we believe that short-term follow-up is adequate to predict the long-term outcomes. Additionally, we used 6 months follow-up to reduce the number of patients lost to follow-up, which increase the validity of the present study.
Dick B, Kohnen et $\mathrm{al}^{14}$ assessed the relationship between corneal endothelial cell loss after phacoemulsification and the location of the clear corneal incision.

The study concluded that superotemporal phacoemulsification incision may entail less ECL as compared to other incisions (although not significantly different). The amount of central ECL may be less marked in patients with longer axial lengths and with procedures utilising less EFT.

Díaz-Valle D, Benítez del Castillo Sánchez JM et al ${ }^{9}$ study evaluated intraoperative endothelial damage after planned Extracapsular Cataract Extraction (ECCE) with difference capsulotomy techniques and phacoemulsification.

The study concluded that endothelial response was not statistically significantly different among the surgical techniques. Beltrame G, Salvetat ML11 compared endothelial damage induced by different cataract incision sites and sizes using specular microscopy.

The study concluded that scleral tunnel group had less postoperative endothelial damage than the clear corneal incision group with a statistically significant difference at the 12 o'clock position. This is probably because the scleral tunnel incision is placed more posteriorly and therefore induces less direct endothelial trauma.

Bourne $\mathrm{RR}$ et $\mathrm{al}^{15}$ to investigate whether modern phacoemulsification surgery results in more damage to the corneal endothelium than Extracapsular Cataract Extraction (ECCE) and to examine which preoperative, operative and postoperative factors influence the effect of cataract surgery on the endothelium.

The study concluded that there is no significant difference in overall corneal endothelial cell loss was found between these 2 operative techniques. The increased risk of severe cell loss with phacoemulsification in patients with hard cataracts suggests that phacoemulsification may not be the optimal procedure in these cases, and that ECCE should be preferred. George R, Rupauliha P, Sripriya AV, Rajesh PS, Vahan PV and Praveen $\mathrm{S}^{4}$ study compared the morphological (Cell density, coefficient of variation and standard deviation) and functional (Central corneal thickness) endothelial changes after phacoemulsification versus Manual Small-Incision Cataract Surgery (MSICS).

The study concluded that central corneal thickness, coefficient of variation and standard deviation were maintained in both groups indicating that the function and morphology of endothelial cells was not affected despite an initial reduction in endothelial cell number in MSICS. Thus, MSICS remains a safe option in the developing.

Ruit S, Tabin G, Chang D, Bajracharya L et al ${ }^{6}$ compared the efficacy and visual results of phacoemulsification vs manual suture less Small-Incision Extracapsular Cataract Surgery (SICS) for the treatment of cataracts in Nepal). They concluded that both phacoemulsification and SICS achieved excellent visual outcomes with low complication rates. SICS is significantly faster, less expensive and less technology dependent than phacoemulsification. SICS may be the more appropriate surgical procedure for the treatment of advanced cataracts in the developing world.

Gogate P, Ambardekar P16 compared endothelial cell loss in cataract surgery by phacoemulsification and by Manual Small-Incision Cataract Surgery (SICS) at Tertiary Care Ophthalmic Centre, India. 
The study concluded there were no clinically or statistically significant differences in EC loss or visual acuity between phacoemulsification and SICS, although there was a small difference in the astigmatic shift.

Yamazoe K, Yamaguchi T, Hotta $\mathrm{K}_{\text {et al7 }}$ study evaluated the surgical outcomes of cataract surgery in eyes with a low preoperative corneal endothelial cell density (less than $1000 / \mathrm{mm}^{(2)}$.

The study concluded that modern techniques for cataract surgery provide excellent visual rehabilitation in many patients with a low preoperative ECD. Shorter AL, diabetes mellitus and posterior capsule rupture were risk factors for greater ECD loss and bullous keratopathy.

Waseem Akhter et al ${ }^{17}$ study aimed at quantitatively measure and compare the loss of corneal endothelial cells following Phacoemulsification and Extracapsular Cataract Extraction with posterior chamber intraocular lens implantation.

The study concluded that there is a significant difference in endothelial cell loss after conventional extracapsular cataract extraction as compared to Phacoemulsification.

Takacs AI, Kovacs I et al ${ }^{18}$ study compared the effect of conventional phacoemulsification and femtosecond laserassisted cataract surgery on the cornea.

They concluded femtosecond laser-assisted cataract surgery causes less trauma to corneal endothelial cell.

Zhang J et al ${ }^{19}$ study compared the outcomes of Phacoemulsification (PE) with Manual Small-Incision Cataract Surgery (MSICS) for age-related cataracts than manual phacoemulsification. The study concluded that PE is superior to MSICS in UCVA, but there were no significant differences in visual rehabilitation, ECC loss and complication rates between the two techniques.

\section{CONCLUSION}

- The key factor of ECL in cataract surgery is surgical manipulation in anterior chamber and extraction of nucleus.

- In phacoemulsification group, the manoeuvring was performed in the capsular bag and newer advanced phacoemulsification units with better fluidics reduced the chances of endothelial damage.

- In MSICS group, Viscoexpression of the nucleus significantly reduced the endothelial cell loss.

- To conclude, there was no difference in safety between MSICS and phacoemulsification.

- MSICS is still a safe and cost-effective option in the developing world.

- Proper case selection, diligent surgery and adequate postoperative care are essential to maintain a clear cornea.

\section{REFERENCES}

1. Vogt A. Die sichtbarkeit des lebenden hornhautendotheis. Ein beitrog zur methodik der spaltlampenmikroskopie. Graefe's Arch Ophthalmol 1920;101:123-44.

2. Maurice DM. Cellular membrane activity in the corneal endothelium of the intact eye. Experientia 1968;24(11): 1094-5.

3. Doughty MJ, Aakre BM. Further analysis of assessments of the coefficient of variation of corneal endothelial cell areas from specular microscopic images. Clin Exp Optom 2008;91(5):438-46.
4. George R, Rupauliha P, Sripriya AV, et al. Comparison of endothelial cell loss and surgically induced astigmatism following conventional extracapsular cataract surgery, manual small-incision surgery and phacoemulsification. Ophthalmic Epidemiol 2005;12(5):293-7.

5. Muralikrishnan R, Venkatesh R, Prajna NV, et al. Economic cost of cataract surgery procedures in an established eye care centre in southern India. Ophthalmic Epidemiol 2004;11(5):369-80.

6. Ruit $S$, Tabin $G$, Chang D, et al. A prospective randomized clinical trial of phacoemulsification vs manual sutureless small-incision extracapsular cataract surgery in Nepal. Am J Ophthalmol 2007;143(1):32-8.

7. Yamazoe K, Yamaguchi T, Hotta K, et al. Outcomes of cataract surgery in eyes with a low corneal endothelial cell density. J Cataract Refract Surg 2011;37(12):2130-6.

8. Mencucci R, Ponchietti C, Virgili G, et al. Corneal endothelial damage after cataract surgery: microincision versus standard technique. J Cataract Refract Surg 2006;32(8):1351-4.

9. Díaz-Valle D, del Castillo BSJM, Castillo A, et al. Endothelial damage with cataract surgery techniques. J Cataract Refract Surg 1998;24(7):951-5.

10. Ravalico G, Tognetto D, Baccara F, et al. Corneal endothelial protection by different viscoelastics during phacoemulsification. J Cataract Refract Surg 1997;23(3):433-9.

11. Beltrame G, Salvetat ML, Driussi G, et al. Effect of incision size and site on corneal endothelial changes in cataract surgery. J Cataract Refract Surg 2002;28(1):118-25.

12. Silva RA, Jain A, Manche EE. Prospective long-term evaluation of the efficacy, safety, and stability of the phakic intraocular lens for high myopia. Arch Ophthalmol 2008;126(6):775-81.

13. Storr-Paulsen A, Norregaard JC, Ahmed S, et al. Endothelial cell damage after cataract surgery: divide-and-conquer versus phaco-chop technique. J Cataract Refract Surg 2008;34(6):996-1000.

14. Dick B, Kohnen T, Jakobi KW. Endothelial cell loss after phacoemulsification and 3.5 vs $5 \mathrm{~mm}$ corneal tunnel incision. Opthalmologe 1995;92(4):476-83.

15. Bourne RR, Minassian DC, Dart JK, et al. Effect of cataract surgery on the corneal endothelium: modern phacoemulsification compared with extracapsular cataract surgery. Ophthalmology 2004;111(4):679-85.

16. Gogate P, Ambardekar P, Kulkarni S, et al. Comparison endothelial cell loss after cataract surgery: phacoemulsification versus manual small-incision cataract surgery: six-week results of a randomized control trial. J Cataract Refract Surg 2010;36(2):247-53.

17. Akhter W, Afzal F, Tayyab A. Comparison of endothelial cell loss between phacoemulsificaiton and extra capsular cataract extraction. Ann Pak Inst Med Sc 2012;8(4):220-3.

18. Takacs AI, Kovacs I, Mihaltz K, et al. Central corneal volume and endothelial cell count following femtosecond laser assisted refractive cataract surgery compared to conventional phacoemulsification. J Refract Surg 2012;28(6):387-91.

19. Zhang JY, Feng YF, Cai JQ. Phacoemulsification versus manual small-incision cataract surgery for age-related cataract: meta-analysis of randomized controlled trials. Clinical \& Experimental Ophthalmology 2013;41(4): 379-86. 